\title{
(RE)CONSTRUCTIONS OF SOCIAL NETWORKS IN SLOVENIAN CASE LAW
}

\section{Kristina ČUFAR ${ }^{1}$}

The article explores the disruptions and puzzles that Slovenian courts encounter when dealing with contested speech on social networks. In recent years, social networks have thoroughly transformed the ways in which we communicate, relate to ourselves and others, disseminate and perceive information, as well as our understanding of privacy and limits of freedom of expression. Social networks are commercial products of private companies, which are more or less autonomous regarding the regulation and moderation of user-generated content they host. However, legal remedies may be activated when such content conflicts with legal norms. An overview of the Slovenian legislative framework and case law involving expression on social networks exposes the ways in which courts (re) construct social networks, as well as the impact and meaning of a disputed online expression. While the case law on the subject cannot be considered established, the overview reveals the strategies that Slovenian courts employ when dealing with the particularities of expression on social networks. The courts, by and large, assume that social networks are special communicative spaces where freedom of expression must be protected and evaluated according to the particularities of social networks. Such understandings may transform the bar of acceptable expression and influence public discussions' tone beyond social networks.

Slovenian legal system

case law

social networks

freedom of expression

contested speech

1 | Teaching Assistant, Faculty of Law, University of Ljubljana, kristina.cufar@pf.uni-lj.si, ORCID: 0000-0002-0688-1094. 


\section{Introduction}

Social networks ${ }^{2}$ are transforming our lives and posing novel challenges for the interpretation of human rights and fundamental freedoms. This article explores various ways in which discourses on social networks challenge the reasoning of Slovenian courts and how discourses on social networks are (re)constructed within the framework of the Slovenian legal system. To illustrate the implications of the widespread use of the Internet and social networks for judicial decision-making, let us consider a concrete example. In the middle of the Covid-19 epidemic, the Constitutional Court of the Republic of Slovenia (Constitutional Court) dealt with a petition to initiate a procedure for the review of the legality of a government decree banning certain types of movement and public gatherings during the epidemic. The court decided to hide the personal data of the petitioner ex officio. ${ }^{3}$ While the reasons are not specified in the judicial decision, the separate opinions of the constitutional judges reveal their backdrop.

In their separate opinion, the judges who supported the suppression of the petitioner's personal data describe intense pressure on the Constitutional Court to reveal the petitioner's identity. ${ }^{4}$ Social networks were bursting with such demands, with online commentators expressing severe judgments of the petitioner along with threats and insults to their person, for instance: 'Purge of these trash is a must!!!!'.5 The judges added that the campaign against the petitioner was further intensified by publishing their alleged identity on a news site that provoked over 100 extremely offensive and vulgar comments. Considering this situation, the judges concluded that the public debate on the matter exceeded all acceptable limits, took into account the petitioner's safety, dignity, and privacy, and stressed that threats and insults against the petitioner might result in a chilling effect that stifles legitimate criticism of the authorities. If the judges in favor of the omission of the petitioner's identity provide several concrete examples of problematic speech on social networks, the judges who voted against such a decision do not engage with the content of the social network campaign against the petitioner. One dissenting judge opined that criticism of government measures indicated voluntary participation in the public debate and stressed that the petitioner did not request the omission of their personal data. ${ }^{6}$ Another dissenting opinion invoked the public's right to information and added criticism of the unusual way of substantiating the decision of the majority who were reading Twitter posts during the session and 'somewhat peculiarly' interpreted them as threats. ${ }^{7}$

2 | Social networks are web-based services that permit users to open a profile or account on which they can share information and opinions, establish connections and communicate with other users. They first appeared in the late 1990s and have since become indispensable part of daily lives for millions of people around the globe. boyd and Ellison, 2007.

3 | Order U-I-83/20-10, Constitutional Court of the Republic of Slovenia, April 16, 2020, para. 15.

4 | Separate opinion of Constitutional Judges Dr. Katja Šugman Stubbs, Dr. Špelca Mežnar and Dr. Rok Čeferin regarding the Order U-I-83/20, paras. 12-15.

5 | Ibid., fn. 12.

6 | Separate opinion of Constitutional Judge Marko Šorli regarding the Order U-I-83/20, para. 6.

7 | Separate opinion of Constitutional Judge DDr. Klemen Jaklič regarding the Order U-I-83/20, para.12. 
While the controversial decision regarding the omission of the petitioner's identity was not at the core of the case before the Constitutional Court, ${ }^{8}$ it highlights how social networks increasingly influence and disrupt all spheres of human activity, including the reasoning of the (highest) courts. The advent of social networks introduced certain particularities in comparison with other social spaces and forums of expression, and thus demands novel approaches in dealing with the limits of freedom of expression. ${ }^{9}$ To engage with these issues, the article first briefly discusses the phenomenon of social networks and their significance for society and legal regulation. A short overview of the Slovenian legal framework establishes (sometimes fuzzy) limits between the public and private expression regulation on social networks. The 'notice and take down' approach adopted in Slovenia implies that individuals can use the legal system to demand that certain user-generated content be deleted or blocked, but no legal remedy is available to legally demand the reinstatement of user-generated content removed by the social networks. ${ }^{10}$ The article then reviews the case law in which social networks play a decisive part, engaging with the decisions of the Slovenian Higher Courts (second instance courts deciding on appeals), the Administrative Court of the Republic of Slovenia (Administrative Court; deciding in administrative disputes), and the Supreme Court of the Republic of Slovenia (Supreme Court; third instance court deciding on extraordinary legal remedies).

The case law involving social networks is too scarce to be considered established; nevertheless, it is an interesting testament to possible legal interpretations of social networks' implications as well as the changes provoked by these networks. The reviewed cases provide juridical reconstructions of the nature of social networks and their average users, the conception of the online public, expectations of privacy in the digital age, the reach of posts on social networks, and their role in circulation of information. The implications of judges' online speech in the judicial system were also explored. Case law reveals the issues encountered by individuals and courts, as well as the strategies employed by the courts thus far. The existing case law on the subject provokes questions regarding the difference between online speech and speech in traditional communicative spaces, as well as the shifting limits of acceptable public discourse.

\section{Regulation of discussion on social networks}

Thanks to social networks, an unprecedented number of people around the globe have access to an outlet allowing them to connect with one another, publicly express their opinions, and exchange information. Slovenia is no exception to the global trends: $87 \%$ of Slovenians aged 16-74 use the Internet regularly ${ }^{11}$ and $82 \%$ have at least one social network account. ${ }^{12}$ Social networks are transforming all aspects of our relating to one another - from language and grammatical rules to the way people access, create, disseminate,

8 | For an in-depth engagement with governmental measures during the first wave of Covid-19 epidemic and the role of the Constitutional Court see: Bardutzky, 2020.

9 | Jereb, 2020.

10 | Toplak, 2020.

11 | Statistical Office of the Republic of Slovenia, 2020.

12 | Valicon, 2020. 
discuss, and perceive information. ${ }^{13}$ The illusion of anonymity online motivates people to express opinions that might otherwise be considered fringe and sometimes makes it difficult to prosecute eventual legal offenses. If the 1990s celebrated the Internet's potential to empower the masses and turn ordinary citizens from mere consumers of news and information into sovereign democratic subjects with agency and far-reaching voices of their own, ${ }^{14}$ the widespread use of social networks also brought an array of problems that beg regulatory responses. Social networks are products of powerful corporations that use algorithms that utilize user information to identify their interests and online behavior to offer content that is assumed to grab users' attention, keep them on platforms for as long as possible, and expose them to as many targeted ads as possible..$^{15}$

While social networks play an important role in empowering individuals and groups, they are also associated with the rapid spread of misinformation and disinformation, echo chambers, copyright abuse, hate speech, and other problematic occurrences. Accordingly, social network companies are forced to engage in content moderation to provide safer spaces for their users and comply with legal requirements. ${ }^{16}$ Although necessary, private content moderation often results in controversial decisions, leading to discussions about the freedom of expression and its limitations. ${ }^{17}$ The term private censorship is sometimes used to criticize the practices of social network companies that regulate and moderate content according to their own regulations and procedures. If human rights often presuppose citizens, social networks assert their sovereignty over users. Excessive removal of user-generated content by social network moderators is a serious issue, and the lack of redress procedures and democratic oversight is highly problematic. ${ }^{18}$ Nonetheless, the debates on private censorship at times lack nuance and focus on the sanctity of the freedom of expression without fully considering its implications for the rights of others. The popular mantras about the marketplace of ideas-where one is always free to respond to the speech of another with their own-neglect that more speech does not necessarily mean better speech and that the limits of the freedom of expression exist precisely to protect the expression (and further rights and freedoms) of others. ${ }^{19}$

These issues are ever-present in the public debate in Slovenia and were perhaps made especially explicit during the 2015 refugee crisis. At that time, the ZLOvenija ${ }^{20}$ Tumblr page appeared and exposed an unprecedented increase in incendiary speech on Facebook's platform. ZLOvenija published instances of hate speech against migrants expressed on public Facebook profiles and groups, along with the names and photographs

13 | E.g. Selak and Kuhar, 2020; Petrič et al., 2015; Fišer, Erjavec, and Ljubešić, 2016.

14 | Barlow, 1996.

15 | E.g.: Vaidhyanathan, 2018.

16 | Gillespie, 2018, pp. 6-24.

17 | To name just two examples: in 2016 Facebook famously removed the photograph 'Napalm Girl' featuring a naked girl fleeing a napalm attack during the Vietnam war, and in 2018 the image of the ancient fertility symbol 'Venus of Willendorf' representing a naked woman a was removed from the platform. Facebook later apologized for the removal and changed the rules regarding artistic depictions of nudity. For more troubling examples of Facebook's content moderation see: Stjernfelt and Lauritzen, 2020.

18 | Klonick, 2018.

19 | Mills Eckert, 2011.

20 | ZLOvenija is a word play on evil ('zlo') and Slovenia ('Slovenija'). 
of the speakers. ${ }^{21}$ The scandal exposed the vulgarity and hatred that ordinary people expressed behind their screens and the disturbingly low levels of public online discussions. ${ }^{22}$ Simultaneously, ZLOvenija opened the issues of privacy, honor, and reputation of those who were publicly shamed online and beyond. As social networks are becoming increasingly popular, the issue of inappropriate online speech is often discussed, and concerns about its impact on social dynamics are frequently raised. The expression on social networks futher complicates already complex issues.

Posts on social networks can swiftly reach wide (even global) audiences and allow for rapid further distribution of the original content. To add to the complexity, the expression on social networks is regulated by both state and non-state actors. Procedures available to those whose expression was silenced and those harmed by such speech were fragmented between different authorities. Therefore, when faced with a contested expression of opinions and ideas on social networks, courts cannot treat it in the same way as expression in traditional forums (physical public spaces, newspapers, etc.). Before we engage with Slovenian case law addressing these dilemmas, a brief overview of the existing regulations is in place.

\section{Slovenian legal system}

The freedom of expression is enshrined in Art. 10 of the European Convention on Human Rights (ECHR), Art. 11 of the Charter of Fundamental Rights of the European Union, and in Art. 39 of the Constitution of the Republic of Slovenia (Constitution). ${ }^{23}$ The latter guarantees the freedom of expression of thought, speech and public appearance, freedom of the press, other forms of public communication and expression, and freedom to collect, receive, and disseminate information and opinions. Freedom of expression is crucial freedom in a democratic society, and it protects even expressions that may shock or offend. Nevertheless, freedom of expression is subject to limitations stemming from both the Constitution and the regional human rights instruments. Constitutional rights that are often invoked as imposing limits on expression are the right to personal dignity and safety (Art. 34), the right to privacy and personal rights (Art. 35), and the prohibition of incitement to discrimination, intolerance, violence, or war (Art.63).

Private companies offering social network services are not bound to guarantee freedom of expression to their users the same way as states and their organizations. There is no case in Slovenian case law where a user would successfully protest a social network's decision to remove user-generated content. ${ }^{24}$ Cases where users successfully demanded

21 | Plesničar and Šarf, 2020.

22 Inappropriate speech on social networks is a widespread phenomenon in Slovenian (social) media-sphere. Vehovar et al., 2020.

23 | Ustava Republike Slovenije (URS, Eng. 'Slovenian Constitution'), Official Gazette RS, No. 33/91-I. 24 | Censored users usually do not have legal remedies at their disposal, though this depends on the jurisdiction. While removal of content in the United States is in the hands of social network companies, German courts hold that social networks function as public communicative spaces and must respect admissible expressions of opinion: while social networks may remove more than just expression illegal under German legislation, they ought not act arbitrarily and must provide recourse procedures. Kettemann and Tiedeke, 2020. 
removals of user-generated content encroaching on their rights, however, are relatively common. Social network companies (service providers under the EU e-Commerce Directive $)^{25}$ may be legally required to expeditiously remove or disable access to usergenerated content upon obtaining knowledge or awareness of its unlawfulness. At the same time, they are generally exempt from liability for such content and are not obliged to seek it out actively. The Slovenian Electronic Commerce Market Act ${ }^{26}$ transposes this approach: service providers are exempt from the liability for user-generated content and are not obliged to monitor this content but are required to stop and prevent violations by removing or blocking user-generated content when prompted by a court order. If a service provider fails to act and such an omission results in damage, the provider may also face civil liability in accordance with the Slovenian Obligations Code. ${ }^{27}$

User-generated content may be deemed illegal for several reasons, as it may establish an administrative, ${ }^{28} \mathrm{criminal}^{29}$ or civil offense. ${ }^{30}$ Moreover, social networks might enter judicial reasoning not only because of potentially illegal user-generated content but, as we have seen in the introductory example, might further complicate a case in other ways. The following section explores in more detail the criteria for evaluating the illegality of speech on social networks, the role social networks play in postmodern society, and the way they are (re)constructed through judicial reasoning.

\section{Social networks in Slovenian case law}

As discussed above, discourse on social networks cannot be equated with discourse in traditional forums of expression. The following pages trace the (re)constructions of the particularities of expressing opinions and ideas on social networks in the case-law of the Slovenian Higher Courts, the Administrative Court, and the Supreme Court. While interesting and thought provoking, the discussed cases are merely exemplary of the strategies employed by the courts when faced with issues stemming from the (ab)use of social networks. The number and relevance of cases discussed are too scarce to infer from them any cohesive narrative that could be said to be prevalent in juridical decision-making when social networks are involved. Nevertheless, the case law presented underlines possible

25 | Directive 2000/31/EC on certain legal aspects of information society services, in particular electronic commerce, in the Internal Market (e-Commerce Directive), Arts. 14 and 15.

26 | Zakon o elektronskem poslovanju na trgu (ZEPT, Eng. 'Electronic Commerce Market Act') Official Gazette RS, No. 97/07, Arts. 8-11.

27 | Obligacijski zakonik (OZ, Eng. 'Obligations Code') Official Gazette RS, No. 97/07, Art. 131.

28 | E.g.: Encouragement of intolerance. Zakon o varstvu javnega reda in miru (ZJRM-1, Eng. 'Protection of Public Order Act') Official Gazette RS No. 70/06, 139/20, Art. 20.

29 | E.g.: Offences against honor and reputation; the prohibition of public incitement to hatred, violence, or intolerance; unlawful publication of private writings; abuse of personal information; the disclosure of classified information; the prohibition of incitement to violent change of the constitutional order; and others. Kazenski zakonik (KZ-1, Eng. 'Criminal Code'), Official Gazette RS, No. 50/12, 6/16, 54/15, 38/16, 27/17, 23/20 and 91/20, Arts. 158-165, 297, 140, 143, 260, 359.

30 | Defamation or calumny, assertion or dissemination of untrue statements on the past, knowledge, or capability of another resulting in material damage; immaterial damage in the form of physical or mental distress suffered owing to the defamation of good name or reputation, the curtailment of freedom or a personal right and fear caused. Obligations Code, Arts. 177 and 179. 
approaches to the issues that will surely preoccupy courts in the future. Furthermore, the case law examined highlights some sociological facets connected to speech on social networks, as understood by the parties and courts.

\section{| 4.1. The nature of social networks and their users}

Slovenian courts have developed different understandings of the nature and particularities of social networks. The Higher Court of Koper, for instance, declared the freedom of expression as a 'precondition of Facebook'. ${ }^{31}$ The case involved a coffee distribution company that claimed to have been damaged by a Facebook post by a local bar that warned against the distributor and its brand of coffee. Based on 'generally known facts about social networks', ${ }^{32}$ the court concluded that even a public Facebook post did not necessarily reach everyone present on the social network and stressed that the defendant's account was not widely known or popular. Considering that the defendant's post was not slanderous but an expression of opinion - and that subjective statements are the standard form of expression on social networks, the court did not award damages to the plaintiff.

At other times, the courts do not seem to take the online context as relevant. The Higher Court of Ljubljana recognized an online comparison of a local major to Hitler who 'shall eat the bills in his filthy snout' 33 as an inappropriate way of expressing political discontent, exceeding the limits of the freedom of expression by encroaching on the honor and reputation of the plaintiff. The court opined that the style of the comment in question was depreciating and could not be understood as a criticism of the mayor's work. The defendant's explanation that he was merely criticizing the mayor, who ignored the incentives and protests of the citizens, was unsuccessful. The judgment does not indicate the exact online setting of the defendant's comment and does not attribute any particularity to the mode of expression.

The expression of political messages and political critique on social networks seems to arouse the cacophony of judicial responses. The same life event may lead to contrasting results, as the two civil law cases provoked by the same offensive Tweet demonstrate. The Tweet in question stated: 'Some brothel FB page offers cheap services of retired prostitutes A. A. and B. B. One for 30 EUR, the other for 35 EUR. \#PimpMilan'. ${ }^{34}$ A politician who was the leader of the largest opposition party in the Slovenian parliament posted a contentious Tweet. ${ }^{35} \mathrm{~A}$. A. refers to an editor-at-large and B. B. to a journalist employed at the public media house RTV Slovenija. ${ }^{36}$ The Tweet was supposedly a response to a news segment exposing alleged links between the defendant's political party and neo-Nazi groups. The editor and the journalist sued the politician in separate civil procedures; both

31 | Judgement Cpg 213/2017, Higher Court of Koper, February 22, 2018, par. 10.

32 | Ibid, par. 9.

33 I Judgement II Cp 701/2015, Higher Court of Ljubljana, May 20, 2015.

34 | Judgement II Ips 75/2019, Supreme Court of the Republic of Slovenia, February 6, 2020, par. 34. 35 | The same politician is currently Slovenian Prime Minister and regularly upsets domestic and foreign public with his Tweets, see e.g.: Higgins, 2021.

36 | The first names of the plaintiffs and the initials of their surnames were included in the original Tweet and are anonymized in the publicly available court decision. The plaintiffs are public personalities, so the court accepted that they were identifiable. RTV Slovenija is occasionally attacked as javna hiša (public house) by certain members of the political class. Javna hiša is a Slovenian term for a brothel. The hashtag 'Pimp Milan' refers to a theory that a retired Slovenian politician is still pulling the strings in the background. 
cases reached the Supreme Court, but the two judgments produced different understandings of the nature of the Twitter social network and the limits of freedom of expression thereon. ${ }^{37}$

Chronologically, the case involving the editor was the first decision. The Supreme Court's decision asserts that the notion of critique and the limits of legally acceptable speech on Twitter differ from those in other settings. The court described Twitter as a social network characterized by a specific style and manner of expression owing to the 280 characters limitation of a single post. According to the court, Twitter engendered a specific subculture whose communication is typified by 'expressive, very brief, fast, also bitter, sardonic, often vulgar reactions written in the vernacular without in-depth reflection.' ${ }^{38}$ This contributes to the 'spontaneous atmosphere' on the platform where an 'average user' consumes Tweets quickly and without in-depth reflection. The average user constructed in the Supreme Court's decision differs from the concept of the average reader of traditional media. Neither average users nor average readers are unambiguous concepts. Yet, the standard of the average user seems to indicate a less attentive person who does not engage in reflection and is used to harsh vulgar tones. In contrast, the average reader is often conceived as a person of average diligence and reason, somewhere between extremely suspicious and extremely naive.

The contentious Tweet might strike an average reader as a verbal attack targeting an individual instead of criticizing their actions, but the Supreme Court opined that an average Twitter user recognized it as a political critique of the plaintiff's editorial work. By placing the message in the context of a specific social network, the court concluded that the defendant expressed his critique through satiric, sarcastic, and offensive verbal caricature without a commentary on the plaintiffs' editorial practice or journalistic reporting. The court recognized that the Tweet was offensive and hurtful to the plaintiff. Nevertheless, the Tweet was not intended to express contempt and devaluation of the plaintiff as a human being. To the contrary, argued the court, it represents a 'highly protected political declaration'. ${ }^{39}$ In the court's opinion, the Tweet in question could be perceived as extremely offensive only when taken literally and outside of its context. Warning against the danger of chilling effect, 'even more daunting on particular social networks like Twitter,' 40 the court decided to prioritize 'the Enlightenment principle of the search for truth through free debate ${ }^{\prime 41}$ and dismissed the plaintiff's demand for damages.

In a separate case decided a year later, the journalist managed to obtain damages. ${ }^{42}$ Considering that the factual basis of the two cases is identical and that the roles of editor and journalist are not grounds for differentiation between them, the Supreme Court considered its previous decision erroneous. The nature of the Twitter social network is conceptualized differently as in the previous decision: 'The use of Twitter communication channel does not grant a communicative carte blanche to anyone, not even an influential oppositional leader, nor can it be used as an excuse for an affective or even premeditated

37 | A criminal procedure involving the same Tweet is still ongoing at the time of writing this article.

38 | Judgement II Ips 75/2019, Supreme Court of the Republic of Slovenia, February 6, 2020, par. 30.

39 | Ibid, par. 34.

40 | Ibid., pars. 35 and 37.

41 | Ibid., par. 39.

42 | Judgement II Ips 22/2021, Supreme Court of the Republic of Slovenia, September 1, 2021. 
action. ${ }^{\prime 3}$ The court opined that the defendant's Tweet lacked argumentation and did not engage with the news segment to which it was supposedly responding. The average reader was thus unable to decipher that the Tweet was meant as a political critique of the plaintiff's journalistic work; the Tweet was understood as an independent whole. The fact that the defendant's discourse was political does not justify the negative value judgment of the plaintiff who was devaluated as a journalist and as a woman, concluded the court.

The Supreme Court perceived the chilling effect differently as in its previous decision regarding the contested Tweet. The second time around, the court construed freedom of expression as protecting not only the political message of the defendant, but also the freedom of the press. Tweets are important means of one-way political communication but are simultaneously intermedia agenda-setting, that is, attempts to pressure traditional media. ${ }^{44}$ While a Tweet by a member of political opposition cannot be considered to have a chilling effect, it nevertheless aimed to influence journalistic practices, opined the court. The court did not engage with the possible chilling effect on the Twitter social network, asserting that the defendant's right to expression of political critique cannot be considered superior to the plaintiff's personal rights. The court stressed that the key problem with the contested Tweet is not its offensive and politically incorrect content but the lack of a factual basis on which the defendant articulated the value judgment as well as the lack of provocation on the plaintiff's side.

\subsection{Concept of the public and the expectations of privacy in the digital society}

When courts deal with a contested speech on social networks, the reach of individual posts is an important consideration. Whether an account is private or public, the number of followers of an account and how long the post remained on the platform are considered. ${ }^{45}$ As we have already seen, courts do not automatically assume that a public account open to everyone equals a universal reach. Likewise, a private account intended to connect with a selected group of friends is not considered harmless automatically.

In the case before the Higher Court of Ljubljana, the plaintiff claimed that his privacy was breached by posting photographs depicting his family life in his home on the defendant's private Facebook account. ${ }^{46}$ The plaintiff stressed that the defendant is also known by young people. ${ }^{47}$ While the court did not see any relevance in the age group to which the defendant's Facebook friends belonged, it nevertheless agreed that even a private post might constitute a breach of privacy. The Facebook album in question, which included photographs taken and published without the plaintiff's permission, was publicly commented upon by five people whose comments were objectively offensive, and even people who were not defendants' Facebook friends might have seen the photographs. The court stressed that even the closest friends represented the public and that the plaintiff's personal rights were breached by the post.

Facebook groups, established to enable communication about shared interests with certain people, also call for nuanced deliberation. A case before the Higher Court of

43 | Ibid., par. 41.

44 | Ibid., par. 36.

45 | E.g.: Judgement II Ips 75/2019, Supreme Court of the Republic of Slovenia, February 6, 2020, par.

23; Judgement Cpg 213/2017, Higher Court of Koper, February 22, 2018, par. 9.

46 | Judgement II Cp 2066/2012, Higher Court of Ljubljana, January 30, 2013.

47 | Ibid., par. 3. 
Ljubljana involved speech in a closed Facebook group of 67 members of the same municipality. ${ }^{48}$ The defendant posted several satirical short stories indirectly mocking the director of the municipal authority, who felt that the posts breached his right to privacy, honor, and reputation. The court considered several circumstances: the plaintiff was a public personality, the posts criticized the plaintiff's conduct as the director of the municipal authority, and they were satirical and critical rather than a personal attack intended to slander. The court also examined the context of the post and established that the fact that the Facebook group was closed 'makes freedom of expression even wider'. ${ }^{49}$ Since the group was intended for the members of the municipality to discuss municipal matters and considering its relatively small membership of citizens who are adequately informed about what goes on in their local community through various means, the court established that the reach of the posts was limited. The court ruled in favor of the defendant and his freedom of expression.

Social networks and contemporary technologies have severe implications for reasonable expectations of privacy. In the case before the Higher Court of Maribor, a high school librarian sued a student who filmed her sultry dance in a masquerade costume..$^{50}$ The defendant posted a video of the dance on his Facebook profile. The video later found its way to YouTube and provoked a slanderous online column by another defendant that was recognized as a breach of her personal rights by the court. The question of filming the plaintiff's dance and posting it on Facebook, however, produced a different decision. Given that the plaintiff was dancing during a recess in the school where she was employed in front of an audience of some 50 students, the court concluded that she exited her private sphere and ought to have expected reactions of the public. The fact that she considered both her costume and dance appropriate led the court to assume that she was not hurt by filming and the subsequent Facebook post. Even though the use of electronic devices was prohibited in the school in question, the plaintiff ought to have expected that the students would nevertheless use their devices to record such an extraordinary event: a person who has been working in the school environment for 18 years is surely aware that the students use modern technology despite the prohibition, opined the court. ${ }^{51}$ The court thus concluded that the student's decision to film the event is completely acceptable, and its publication on social networks is predictable. Since the defendant stated that he was not involved in the subsequent publication of the video on YouTube, the court concluded that his actions did not represent a breach of the plaintiff's personal rights.

The described cases reveal that when faced with privacy issues and social media posts, the courts assess the specific circumstances and context of each publication. Generally, the courts take seriously and issue injunctive orders demanding immediate deletion of posts that breach the privacy of another, for example, by posting their private data. ${ }^{52}$ While the cases described above are all civil law cases dealing with alleged breaches of personal rights, extreme cases also reach the criminal courts and may even result in custodial sentences. In one such case, the Supreme Court stressed that the wide accessibility of social networks and their (ab)use present unprecedented means for encroaching

48 | Judgement II Cp 577/2019, Higher Court of Ljubljana, July 10, 2019.

49 | Ibid., par. 29.

50 | Judgement and order I Cp 193/2012, Higher Court of Maribor, May 8, 2012.

51 | Ibid., par. 20.

52 | E.g.: Order I Cp 2892/2017, Higher Court of Ljubljana, January 24, 2018. 
on privacy, honor, and reputation of others, and that the consequences in such cases are much graver for the victims than if the same criminal offenses were executed by means of traditional media..$^{53}$ Other criminal offenses may also be committed through (ab)use of social networks - for instance, incitement to violent change of the constitutional order, as in the case of an armed group that used social networks to recruit others to join their rebellion against the authorities. ${ }^{54}$ The cases discussed thus far reveal that the unrivaled possibility of expressing oneself coupled with the wide reach of social networks also presents unparalleled risks for abuse.

\subsection{Social networks as sources of information}

The overview of case law presented thus far dealt with the (un)problematic content and the limits of freedom of expression on social networks. However, social networks are more than just communicative platforms, as they present an extremely important source of information for many people. The role of social networks as vessels of information is often discussed in the context of the problematic spread of misinformation and disinformation eroding public trust and contributing to general cynicism. However, the Slovenian legal system does not contain specific provisions dealing with these issues. ${ }^{55}$ Since social networks host user-generated content and, despite active content moderation on many platforms, do not have editors in the traditional sense of the word, the Slovenian definition of a media organization in the Mass Media Act does not include social networks. ${ }^{56}$ Case law reveals that the courts nevertheless acknowledge the role of social networks in public access to information, which is an important aspect of the constitutional freedom of expression.

An administrative dispute between a local mayor and the members of the municipal council was brought before the Administrative Court to decide who should control the official municipal Facebook page and the municipal newsletter. ${ }^{57}$ The root of the dispute was the municipal council's decision to transfer control over the Facebook page and newsletter to the editorial council. The mayor disagreed with the decision, arguing that both national and municipal regulations imposed the right and duty to inform the public on the mayor. The court agreed with the plaintiff's claim that in the present era, social networks are as important for the informing of the public as traditional media and confirmed that ensuring prompt information to the citizens is an essential part of the mayor's function.

53 I Judgement, I Ips 13079/2012-183, Supreme Court of the Republic of Slovenia, September 17, 2015, par. 18.

54 I Judgement II Kp 40945/2018, Higher Court of Maribor, September 12, 2019; Judgement XI Ips 40945/2018, Supreme Court of the Republic of Slovenia, October 22, 2018.

55 | Removal of mis- and disinformation is mostly in the hands of social networks. The Code of Practice on Disinformation was agreed upon by the European Commission, platforms, leading social networks, advertisers and advertising industry. Through this self-regulatory instrument, the industry has voluntarily agreed to a set of worldwide standards to fight disinformation and committed to periodic monitoring. European Commission plans to substitute the Code with European Democracy Action Plan by 2023. The plan will be based on tree pillars: promoting free and fair elections, strengthening media freedom and pluralism, and countering disinformation. European Commission, 2017. 56 | Media organizations are defined as newspapers, magazines, radio and TV programs, electronic publications, teletext and other forms of daily or periodical publishing of edited content via text, voice, sound or image available to the public. Zakon o Medijih (ZMed, Eng. 'Mass Media Act'), Official Gazette RS No. 35/01, 62/03, Art. 2.

57 I Judgment II U 18/2016, Administrative Court of the Republic of Slovenia, February 7, 2017. 


\subsection{Judges on social networks}

Courts, the main protagonists of this article, are human institutions. It is thus not surprising that judges, like most people, tend to use social networks. The Ethics and Integrity Commission at the Judicial Council of the Republic of Slovenia produced guidelines for public expression of judges on social networks as a response to a highly publicized case of a judge who expressed critique of the government's handling of the Covid-19 epidemic on her private Facebook profile. ${ }^{58}$ The posts in question became public through one of the judge's Facebook friends who leaked it to a sensationalist news site. The disciplinary procedure found that the judge did not act inappropriately since judges enjoy freedom of expression and political action, albeit in a somewhat restricted form.

The judges' freedom of expression is partially limited to protect the integrity, independence, and impartiality of the judicial system. The Ethics and Integrity Commission's guidelines, based on those of the United Nations Global Judicial Integrity Network and the European Network of Councils of Judiciary, address several aspects of social network usage by the judges. The judges must refrain from investigating social networks when working on a case - for instance, browsing the profiles of witnesses. Judges ought to be careful when choosing their online friends and constantly review, delete and block potentially problematic Facebook friends. Judges must be cautious and prudent when expressing their opinions and must refrain from any discriminatory comments and insults. The Ethics and Integrity Commission also stresses that there is no difference between private and public accounts. Therefore, judges must always keep in mind that even a private post might become public and act accordingly. They must also adjust their behavior in the physical world, as they might be photographed or filmed at any time and published on social networks. Judges must also exercise caution when liking and sharing content on social networks and joining online groups.

Social networks are significant for the functioning of the legal system in a myriad of ways, not only as communicative spaces where the law might be breached but also as forums of (self-)expression that might influence the popular perception of impartiality and independence of public institutions. The judges are now dealing with another aspect of their private lives that must conform to the nature of the important public function they perform, as everyone's private lives are exposed to increasing societal control through the advancement of commercial technology.

\section{Discussion}

The overview of relevant case law demonstrates that the courts are vigilant when it comes to unlawful breaches of privacy, yet they also consider that we live in a world where (the means of) communication have changed, leading to lower expectations of privacy in public settings. Both ordinary individuals and judges themselves are increasingly surrounded by personal devices capable of photographing, filming, and distributing content online. Technologies such as smartphones and social networks, have already transformed our lives and our relationship with the notion of privacy, which is reflected

58 | Guidelines Su Ek 23/2020-9, Judicial Council of the Republic of Slovenia Ethics and Integrity Commission, March 2, 2021. 
in the reasoning of the courts. The means of expressing oneself have also transformed, amplified the voices of individuals, and the possibilities for and consequences of abuse of the freedom of expression. ${ }^{59}$ Social networks are relatively new communicative spaces, and the expression of ideas and opinions in this setting has certain particularities that (sometimes) influence judicial decisions. Moreover, social networks are considered a source of information, not only as communicative platforms.

Engagement with case law indicates that the courts carefully dissect the circumstances of each case when it comes to deciding whether a social network post may be considered a breach of personal rights. The courts do not rely on fixed criteria of public and private profiles and groups in assessing the nature and impact of a post; rather, they try to establish the reach and impacts of a post by placing it in a specific context. Indeed, the diverse approaches of the analyzed decisions make it rather difficult to establish a common thread or a set of criteria that courts use when confronted by a contested post on social networks. Each case is specific, and flexibility in evaluating its specific context is important. Nevertheless, decision-making seems somewhat arbitrary. Individual judges' perceptions of the nature and role of social networks seem to play an important part in how the courts respond to alleged violations of personal and other rights on social networks. The evident trend is that the courts often provide conclusions regarding the nature of social networks and their particularities, although their reconstructions are diverse.

The two cases involving the same historical event decided by the Supreme Court in two different ways illustrate the open-endedness of the courts' conceptualizations of communication on social networks and its relevance to the outcome of a case at hand. ${ }^{60} \mathrm{In}$ the case that was decided first, the Supreme Court recognized what might be considered an ad personam attack as political critique in need of protection, evoking the pursuit of the truth and Enlightenment principles and the specific manner of expressing opinions in Twitter subculture. ${ }^{61}$ This is the most dramatic example of a lowering standard of acceptable speech on social networks in the Slovenian case law. It seems that some judges concede to the idea that the medium of expression may justify otherwise unacceptable speech - a testament to our times where in-depth reflection, research, and arguments are increasingly sidelined by name-calling and generalized claims. Offensive and vulgar speech, supposedly specific to this social network, is omnipresent and heavily influences public debate.

When the same life event was tried by a slightly different panel of the Supreme Court judges, a completely different reconstruction of communication on Twitter was produced. ${ }^{62}$ The (chronologically) subsequent judgment does not construe Twitter as a particular subculture in which the level of acceptable expression is lower than elsewhere. Neither is the limitation of a single Tweet's length by the social network company perceived as an explanation for the lack of arguments or reference to the news segment that the defendant was supposedly criticizing. Even the concept of the average user

59 | E.g.: Judgement, I Ips 13079/2012-183, Supreme Court of the Republic of Slovenia, September $17,2015$.

60 I Judgement II Ips 75/2019, Supreme Court of the Republic of Slovenia, February 6, 2020, and Judgement II Ips 22/2021, Supreme Court of the Republic of Slovenia, September 1, 2021.

61 | Judgement II Ips 75/2019, Supreme Court of the Republic of Slovenia, February 6, 2020.

62 | Judgement II Ips 22/2021, Supreme Court of the Republic of Slovenia, September 1, 2021. 
introduced in the first case is substituted by the concept of the average reader. In the subsequent decision, the average reader is not presupposed to be aware of the full context of the Tweet in question, as was the case in the (chronologically) prior decision. According to the court, the average reader does not understand the contentious Tweet as a mere disagreement with the public media house and its editorial policies. On the contrary, the Tweet is perceived as a personal attack on the journalist and is questioning her independence, impartiality, and credibility. The two plaintiffs thus obtained strikingly different outcomes, even though their lawsuits were based on the same Tweet.

The fact that the two practically identical cases were decided in two diametric ways by the third instance court is thought-provoking. In the Slovenian legal system, the Supreme Court plays an important role in the unification of jurisprudence. A single Supreme Court judgment does not constitute an established case law, and furthermore, the established case law may be bypassed if a court offers sufficient arguments for the divergence. In the subsequent decision, one of the dissenting judges finds the outcome of the two procedures unacceptable, invoking legal certainty and arguing that arriving at the same conclusion in two identical cases is more important than arriving at the right conclusion. ${ }^{63}$ Such reasoning leaves something to be desired, as the importance of established case law lies beyond a formal guarantee of legal certainty, and is therefore open to transformation. The same dissenting judge also referred to the nature of Twitter as a counterweight to the manipulative practices of traditional media, especially the public media house. ${ }^{64}$ Such a reconstruction is not present in either judgment of the Supreme Court. Furthermore, the question of the acceptable expression of critique cannot be avoided simply by declaring a specific social network particularly vulgar. The issues discussed in this article thus remain open and contentious. It will be interesting to observe the future strategies of the courts and eventual decision(s) by the Constitutional Court and the European Court of Human Rights. Future cases decided by Slovenian courts will also contribute to the development of established conceptualizations of social networks. Before the case law is fully established, diverse and case-specific (re)constructions of social networks are likely to remain prevalent.

\section{Conclusions}

The transformations of communication and societies provoked by social networks are a global phenomenon. Like all jurisdictions, the Slovenian legal system is negotiating the impacts of living in a digital society. The fact that more people can reach wider audiences has many positive effects on society, as the previously invisible stories can emerge and marginalized groups gain the possibility to connect and have a voice. At the same time, more (and louder) speech is a double-edged sword, as problematic speech also gains a platform. The consequences of such expression of opinions and ideas might cause harm to individuals, but its consequences also concern society as a whole, inducing higher levels of cynicism, desensitization, and polarization. Problematic discourse on social networks

63 | Separate opinion of Supreme Court Judge Jan Zobec regarding the Judgment II Ips 22/2021, par. 16.

64 | Ibid., par. 53. 
is distributed extremely fast, gains a lot of (media) attention, sparks controversy, diverts from more important issues, lowers the standards of public debates, and causes lasting consequences that injunctive orders cannot fully prevent. Social networks are widely used in political communication, and traditional media often distribute social network posts; therefore, the reach of expression on such platforms goes far beyond the scope of their (average) users. ${ }^{65}$ In extreme cases, problematic online expressions might spill over and materialize in the physical world.

Within this context, the article engaged with the multidimensional impact of social networks on the Slovenian judicial system. Whether judges themselves express their opinions on social networks or evaluate the context and content of such expressions of others, the rules of the game seem to be changing. The reviewed case law indicates that the courts perceive social networks as important forums of public expression and seek to avoid the chilling effect and overt restrictions of the freedom of expression online. As public debates online are becoming ever more polarized and brutal, it seems that the courts are adopting different strategies and conceptualizations of social networks and the acceptable level of communication thereon. The case law involving social networks is not established, and a reliable set of criteria guiding judicial decision-making is not in place. The relevance of (specific) social networks is thus decided arbitrarily, taking into account the specific context of each case. Surely, the courts will be dealing with more cases involving social networks in the future, and the strategies reviewed in this article will be further developed and consolidated. However, technological developments will certainly pose new challenges that will have to be accommodated by the legal system. The judicial system will have to adapt and invent responses to our changing realities. As the stakes soar, we are in for an interesting ride. 


\section{Bibliography}

Bardutzky, S. (2020) 'Limits in Times of Crisis: On Limitations of Human Rights and Fundamental Freedoms in the Slovenian Constitutional Order', Central European Journal of Comparative Law, 1(2), pp. 9-31.

Barlow, J.P. (1996) 'A Declaration of the Independence of Cyberspace', Electronic Frontier Foundation. [Online] Available at: https://www.eff.org/cyberspace-independence (Accessed: 16 August 2021).

boyd, d.m. and Ellison, N.B. (2007) 'Social Network Sites: Definition, History, and Scholarship', Journal of Computer-Mediated Communication, 13(1), pp. 210-230.

European Commission (2017) 'Tackling Online Disinformation' [Online] Available at: https://ec.europa.eu/digital-single-market/en/tackling-online-disinformation (Accessed: 18 March 2021).

Fišer, D., Erjavec, T. and Ljubešić, N. (2016) 'JANES v0.4: Korpus slovenskih spletnih uporabniških vsebin', Slovenščina 2.0: empirical, applied and interdisciplinary research, 4(2), pp. 67-99.

Gillespie, T. (2018) Custodians of the Internet: Platforms, Content Moderation, and the Hidden Decisions That Shape Social Media. United States of America: Yale University Press.

Higgins, A. (2021) ‘Wielding Twitter, Europe's 'Marshal Twito' Takes Aim at the Media' [Online]. Available at: https://www.nytimes.com/2021/06/16/world/europe/sloveniajansa-press-freedom-twitter.html (Accessed: 25 October 2021).

Jereb, A. (2020) 'Žaljive objave na družbenih omrežjih kot moderni izziv sodišč: So lahko tudi všečki protipravni?', Pravni Letopis 2020, pp. 175-199.

Kettemann, M.C., and Tiedeke S.A. (2020) 'Back up: Can Users Sue Platforms to Reinstate Deleted Content?', Internet Policy Review, 9(2), pp. 1-20.

Klonick, K. (2018) 'The New Governors: The People, Rules, and Processes Governing Online Speech.' Harvard Law Review, 131(6), pp. 1598-1670.

Mance, B. (2014) 'Odnosi med novinarji in politiki na Twitterju', Javnost - The Public, 21(1), pp. 23-40.

Mills Eckert, L. (2011) 'A Critique of the Content and Viewpoint Neutrality Principle in Modern Free Speech Doctrine', Law, Culture and the Humanities, 7(2), pp. 264-288.

Petrič, G., Rogelj, A., Petrovčič, A. and Dremelj, P. 2015. 'Opolnomočenje v spletnih podpornih skupinah za ljudi s težavami v duševnem zdravju: Vloga podpornega komuniciranja in motivov za uporabo.' Teorija in Praksa, 52(5), pp. 865-1004.

Plesničar, M.M., and Šarf, P. (2020) “"This Web Page Should Not Exist”: A Case Study of Online Shaming in Slovenia' in Trottier, D., Gabdulhakov, R. and Huang, Q. (eds.) Introducing Vigilant Audiences. Cambridge: Open Book Publishers. 
Selak, Š. and Kuhar, M. (2020) ‘Socialno-psihološki vidik uporabe spletnega socialnega omrežja Facebook skozi prizmo dejavnikov selektivnega samopredstavljanja', Teorija in Praksa, 57(2), pp. 622-645.

Statistical Office of the Republic of Slovenia (2020) 'Uporaba interneta v gospodinjstvih in pri posameznikih, podrobni podatki, Slovenija, 2020' [Online] Available at: https:// www.stat.si/StatWeb/News/Index/9258 (Accessed: 16 February 2021).

Stjernfelt, F. and Lauritzen, A.M. (2020) 'Facebook's Handbook of Content Removal' in Stjernfelt, F. and Lauritzen, A.M. (eds.) Your Post Has Been Removed: Tech Giants and Freedom of Speech. Cham: Springer International Publishing.

Toplak, J. (2020) 'Svoboda izražanja bo zbledela, dobrodošli v čase zasebne cenzure', Pravna Praksa 39(33), p. 3.

Vaidhyanathan, S. (2018) Antisocial Media: How Facebook Disconnects Us and Undermines Democracy. Oxford University Press.

Valicon (2020) 'Uporaba družbenih omrežij in storitev klepeta v Sloveniji 2018-2019', [Online] Available at: https://www.valicon.net/sl/2020/01/uporaba-druzbenihomrezij-in-storitev-klepeta-v-sloveniji-2018-2019/ (Accessed 16 February 2021).

Vehovar, V., Povž, B., Fišer, D., Ljubešič, N., Šulc, A. and Jontes, D. (2020) ‘Družbeno nesprejemljivi diskurz na Facebookovih straneh novičarskih portalov', Teorija in Praksa 57(2), pp. 622-645. 